\title{
Pendidikan Janin pada Masa Pre-natal (kehamilan) sampai dengan Post-natal (pasca persalinan) Ditinjau dari 6 Kategori Rumpun Pendidikan Islam dan Asas Hikmah
}

\author{
Permana Octofrezi \\ Sekolah Tinggi Agama Islam Masjid Syuhada Yogyakarta
}

\begin{tabular}{|c|c|}
\hline INFO ARTIKEL & ABSTRAK \\
\hline Riwayat Artikel: & Abstract: To get a quality and pious generation, ideally, parents prepare it \\
\hline Diterima: $10-04-2020$ & arly age, namely, to educate from a child in the mother's womb. \\
\hline Disetujui: 03-06-2020 & period (pregnancy to postpartum period). In detail, this manuscript reveals \\
\hline Kata kunci: & $\begin{array}{l}\text { pre-natal Islamic education; Second, what is the description, way, and } \\
\text { knowledge of Islamic education in the post-natal period. }\end{array}$ \\
\hline $\begin{array}{l}\text { Pendidikan Islam } \\
\text { Pre-natal } \\
\text { Post-natal }\end{array}$ & $\begin{array}{l}\text { Abstrak: Untuk memperoleh generasi yang berkualitas dan bertaqwa, } \\
\text { maka idealnya orangtua mempersiapkannya sejak dini, yakni mendidik } \\
\text { sejak anak di dalam kandungan ibunya. Artikel ini memaparkan tentang } \\
\text { pendidikan islam masa pre-natal \& post natal (masa kehamilan sampai } \\
\text { dengan masa pasca persalinan). Secara detail, naskah ini mengungkapkan } \\
\text { tabir beberapa hal yakni : Pertama, bagaimana definisi, bentuk dan hikmah } \\
\text { pendidikan islam masa pre-natal ; Kedua, bagaimana definisi, bentuk dan } \\
\text { hikmah pendidikan islam pada masa post-natal. }\end{array}$ \\
\hline
\end{tabular}

\section{Alamat Korespondensi:}

Permana Octofrezi,

Sekolah Tinggi Agama Islam Masjid Syuhada Yogyakarta

JL. Raya Lubuk Begalung Padang - Sumatera Barat, Indonesia

Jl. Pringgokusuman No.12, Pringgokusuman, Gedong Tengen, Kota Yogyakarta, Daerah Istimewa Yogyakarta 55272

E-mail: octofrezi@gmail.com

\section{PENDAHULUAN}

Permulaan tahap pendidikan selama ini identik dengan pendidikan setelah anak lahir atau pendidikan anak sejak usia dini. Padahal pada masa ketika anak dalam kandungan pun sudah bisa di-didik dengan pendidikan islam. Mulai dari membaca do'a sebelum hubungan suami-istri dengan tujuan agar benih yang menjadi cikal bakal anak nanti dijauhi dari syaithon, berkomunikasi dengan janin dalam kandungan sang ibu, sampai. Menyusui dan menyapih. Berkomunikasi dengan janin misalnya dengan cara mengelus-elus perut, membacakan cerita, membacakan ayat-ayat Al- Qur'an maupun doa-doa harian.

Masa Prenatal adalah masa dimana janin masih dalam kandungan sebelum dilahirkan. Sedangkan Postnatal merupakan kelanjutan dari prenatal dimana janin sudah lahir dan sudah bisa dinamakan bayi baru lahir (newborn). Di masa postnatal inilah bayi secara visualisasi bisa nampak nyata respon yang diberikan orang tuanya dan lingkungan sekitar yang mendidiknya.

Bayi/Janin dalam kandungan sudah dapat mendengar suara-suara dari luar. Janin bisa distimulus melalui sentuhan kulit ataupun rabaan tangan dari manusia diluar. Ketika diraba janin merespon dengan 
bergerak-gerak atau menendang-nendang perut ibunya. Hal ini terlihat secara seksama dari perut ibu yang bergerak dari dalam, menyundul-nyundul dengan kulit perut yang terangkat-angkat mengikuti gerakan janin. Pergerakan janin ini menandakan kondisi sehat dan janin berkembang sangat baik, sehingga perlu distimulus untuk memancing kecerdasan.

Pembahasan ini dibatasi sampai pasca persalinan pada usia disapih yakni sekitar dua tahun. Mulai dari berbentuk janin sampai berbentuk bayi seutuhnya. Penulis berupaya menyampaikan isi pembahasan secara sistematis, terperinci dan terkategorisasi sesuai rumpun ilmu atau cakupan materi dari pendidikan islam yang diterapkan kepada janin dalam kandungan maupun bayi yang sudah atau baru lahir. Dari beberapa uraian di atas, maka permasalahan yang terkait dengan penelitian ini dapat diidentifikasikan sebagai, bagaimana pendidikan islam pada janin masa prenatal (dalam kandungan)? Bagaimana pendidikan islam pada bayi masa postnatal (pasca persalinan)?

\section{METODE}

Metode penelitian ini menggunakan studi kepustakaan. Data-data yang diteliti berupa buku-buku, jurnal ilmiah, ataupun sumber-sumber referensi lainnya yang relevan dengan penelitian, yaitu tentang bagaimana pendidikan islam pada janin usia kandungan sampai pasca persalinan yang sudah berwujud bayi. Peneliti mencari, menelaah dan menganalisa data-data yang berasal dari berbagai literatur, buku-buku dan sumber pustaka lainnya yang diperlukan. Pada akhirnya studi kepustakaan ini menghasilkan beberapa simpulan berdasarkan kajian yang telah dilakukan sebelumnya

\section{HASIL \& PEMIBAHASAN}

\section{Pendidikan Islam pada Janin masa Prenatal}

Istilah Prenatal berasal dari kata pre dan natal. Pe berarti sebelum dan natal berarti lahir, sehingga jika digabungkan artinya adalah sebelum kelahiran. Dalam pandangan psikolog, prenatal adalah aktifitas aktifitas manusia sebagai calon suami istri yang berkaitan dengan hal-hal sebelum melahirkan yang meliputi sikap dan tingkah laku dalam rangka untuk memilih pasangan hidup agar lahir sehat jasmani dan rohani. Pada tingkat pemilihan pasangan inilah pendidikan yang diberi akan berpengaruh pada perilaku yang berlanjut pada kelahirannya.

Pendidikan islam yang syaamil dan kaafah (sempurna) terdiri dari beberapa kategori rumpun yakni : Pendidikan Aqidah, Pendidikan Akhlak, Pendidikan Fiqh (ibadah), Pendidikan Syari'at, Pendidikan AlQur'an-Hadits, serta Pendidikan Sejarah dan Kebudayaan Islam (Tarikh). 6 (enam) kategori tersebut tidak hanya bisa diajarkan pada usia sekolah atau pra-sekolah saja, bahkan bisa diajarkan sedini mungkin sejak janin masih di dalam kandungan ibunya. Bagan visualisasi 6 Kategori Rumpun Pendidikan Islam yang bisa ditanamkan pada anak usia kandungan dan pasca persalinan dapat dilihat pada Gambar 1.

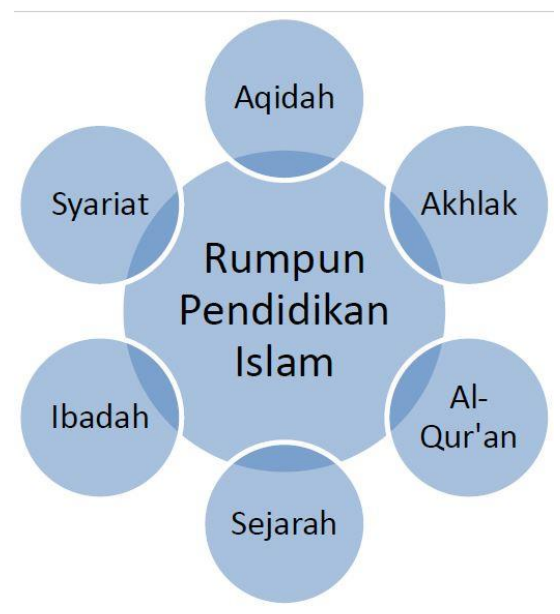

Gambar 1. Rumpun Pendidikan Islam 
Semua rumpun pendidikan islam diatas sudah bisa ditanamkan sejak dini bahkan diajarkan sejak janin di dalam kandungan agar pendidikan islam ini seimbang dan selaras dengan perkembangan fisik dan psikisnya. Keseimbangan dan keselarasan ini yang sesuai dengan fitrah manusia selaku hamba-Nya.

Pendidikan islam pada anak usia kandungan ini diperuntukkan secara khusus kepada kedua Ayah dan Ibu sang janin, terutama ibu yang mengandung. Dalam proses pendidikan, yang menjadi Peserta didik adalah janin itu sendiri dan orangtuanya selaku guru atau pentransfer ilmu. Berikut cara mendidik anak dalam pendidikan islam semasa pre-natal yang telah disusun sesuai kategori rumpun materi pendidikan agama islam, yaitu :

\section{Pendidikan Akhlak.}

\section{Mendo'akan janin}

Anugerah terbesar bagi pasangan yang sudah menikah adalah memiliki keturunan. Bagi yang sudah lama menikah tetapi belum juga dikarunia anak mesti memiliki harapan yang besar untuk segera memilili keturunan yang diidamkannya. Harapan ini yang diwujudkan melalui do'a-doa yang dia panjatkan secara pribadi kepada Allah maupun meminta do'a dari orang lain baik itu orangtua, keluarga ataupun para 'alim ulama. Sosok sang Ayah begitu tahu istrinya mengandung tentu memiliki keinginan tentang sosok anak seperti apa yang ia dan istri idam-idamkan. Tentu inilah yang memotivasi Ayah dan Ibunya.

Isi doa pada umumnya calon Ayah dan Ibu secara fisik menginginkan bayinya terlahir normal, sehat, tampan atau cantik. Kalau keinginan non fisik seperti ingin memiliki anak yang patuh terhadap orangtuanya, sholeh/sholehah, pintar, rajin, menjadi anak yang berguna dan lain sebagainya. Harapan memiliki anak bagi hamba Allah tersirat dalam Al- Qur'an pada ayat berikut :

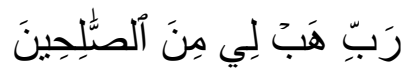

Ya Tuhanku, anugrahkanlah kepadaku (seorang anak) yang termasuk orang- orang yang saleh. [As Saffat:100]. Mendoakan janin semasa prenatal secara teknis bisa dibagi dalam waktu- waktu tertentu misal diawali dari berdo'a ketika mengetahui kehamilan pertama kali sampai do'a selama perkembangan janin dari bulan ke bulan. Hikmah dari mendoakan janin ini adalah adanya keyakinan dan keyakinan orang tua yang meminta campur tangan Allah untuk memberikannya keturunan yang sholih-sholihah, dan keinginankeinginan lainnya yang sesuai harapan orangtua selaku peminta. Hikmah lainnya adalah adanya rasa takut dan harap. Takut kalau Allah tidak mempercayainya mengasuh anak, dan berharap Allah memberikannya keturunan. Rasa takut dan harap inilah yang bisa melunakkan hati hambanya serta dapat meningkatkan ketakwaannya kepada Allah.

\section{Membangun komunikasi pada janin}

Ketika janin berumur 120 hari, maka beberapa indera mulai terbentuk . Indera pendengaran janin sudah mulai berfungsi, sehingga bisa mendengar aktifitas-aktifitas di luar rahim ibunya. Sejatinya anak sudah bisa diajak berkomunikasi meski tidak bisa melihat secara langsung, tetapi bisa dirasa melalui pergerakan janin di lapisan kulit ketika menerima respon dari luar, baik sentuhan tangan, rabaan, elusan dari orang tuanya. Perlunya membangun komunikasi dengan janin baik dari ibu maupun sang ayah. Semenjak usia 4 bulan ketika indra dan organ-organ janin sudah terbentuk, salah satunya indra pendengaran janin.

Janin sudah bisa merespon sentuhan jari orangtuanya, bentuk respon bisa berupa gerakan. Gerakan ini bisa terlihat dari sisi kulit perut ibu yang mengandung seolah-olah janin menendang-nendang kakinya atau mengerakkkan tangannya. maka indra tersebut bisa di stimulus. Komunikasi bisa dilanjutkan sampai menjelang persalinan. Sang ibu dan ayah janin bisa mengajak janin mengobrol "nak, keluarnya jangan lamalama ya kasihan ibu kesakitan, dedek normal ya lahirnya dan sehat!." Biasanya janin akan bereaksi, bergerak-gerak menerima respon dari suara sang ayah/ibu. Komunikasi menjadi kunci peranan yang penting bagi perkembangan anak. Hikmah dari komunikasi dengan janin ini, dengan adanya komunikasi secara emosional maupun fisik terjadi hubungan antar anak dengan orang tua, menjalin dan menguatkan ikatan dalam suasana yang menyenangkan (Harini \& Al-Halwani, 2003). 


\section{Pendidikan Ibadah}

\section{Sholat wajib}

Pendidikan sholat hendaknya mulai diajarkan sedini mungkin kepada anak, bahkan sejak janin. Pada hakikatnya, sholat membuat kedekatan seorang hamba dengan tuhannnya. Ibu hamil yang beribadah sholat secara langsung mengikutsertakan janin yang dikandungnya untuk turut sholat. Mendidik janin dengan mengikutsertakannya sholat contohnya adalah jika akan mendirikan sholat, ibu yang mengandungnya berkata : "Nak, Ayo sama-sama kita sholat ya. (Ak, 2000) Pendidikan sholat pada janin tidak hanya sekedar mengikutsertakan janin dalam menunaikannya saja, tetapi dalam hal waktu harus disiplin tepat di awal waktu tanpa menunda-nunda dengan harapan besok ketika besar sang anak juga disiplin melaksanakan ibadah sholat lima waktu. (Mansur, 2009). Hikmahnya adalah memberikan insting melaksanakan ibadah sholat wajib dengan tepat waktu, mentaáti kewajiban Allah dan sesuai dengan fitrah manusia yang mengabdi kepada Tuhannya.

\section{Sholat Sunat}

Disamping sholat wajib lima waktu, Sholat sunnah pun menjadi amal ibadah yang tepat dalam mengisi hari-hari sang ibu dan janin yang akan di-didiknya. Ibu yang mendambakan anaknya sholeh tentu saja tidak cukup puas dengan beribadah yang wajib/pokok saja, namun perlu menambahnya dengan sholat- sholat sunat. Jika kita urutkan sholat sunnah, mulai dari pagi yaitu sholat sunat fajar sebelum subuh, sholat dhuha, sholat rawatib yang dikerjakan sebelum maupun sesudah sholat fardhu, sholat tahajud yang dikerjakan pada sepertiga malam, sholat witir dan sholat sunat lainnya. Di antara sholat-sholat sunat tersebut yang menjadi sholat sunat yang utama adalah sholat tahajud. Sang Ibu bisa menerapkan sholat tahajud ini.

Hikmahnya bagi sang janin adalah dapat membenarkan posisi janin yang siap lahir. Ketika sholat sunat sang ibu dapat memperlama sujud (dalam penelitian medis, hikmah dari sujudnya seorang ibu hamil adalah dapat menghindari posisi bayi lahir sungsang). Selain itu, sujud dalam memperlancar peredaran darah di otak karena sewaktu sujud posisi kepala menjadi rendah sehingga membuat darah banyak mengalir ke otak dan terhindar dari segala penyakit termasuk kanker (Suparman, 2015). Dalam sujud juga bisa memanjatkan do'a-do'a terkhusus do'a untuk sang janin.

\section{Bersodaqoh}

Sodaqoh merupakan bentuk bentuk pemberian seseorang kepada orang lain sesuai takaran kemampuan baik berupa materi (harta), maupun non materi seperti jasa atau tenaga. Hikmah dari Ibu hamil yang bersodaqoh secara batin ingin mendidik janin yang dikandungnya agar memiliki rasa empati kepada orang lain. Sodaqoh bisa berupa sedekah ke masjid, memberi uang saku kepada anak yatim dan lain sebagainya (Aziz, 2017). Selain itu Hikmah sodaqoh dalam islam memberikan dampak menolak bala dan memudahkan segala urusan termasuk urusan perkembangan janin, urusan proses persalinan dengan harapan bayi yang dilahirkan lancar, normal sesuai harapan orang tua dan keluarga.

\section{Mengikuti majelis taklim dan berkumpul dengan orang sholeh}

Mendidik janin dengan mengikutsertakannya hadir ke pengajian atau majelis taklim akan menstimulus janin agar terbiasa dengan lingkungan yang islami, bergaul dengan orang-orang sholeh yang terdiri dari jama'ah yang ada di dalam majelis (Ak, 2000). Terutama ketika indera pendengaran janin yang sudah mulai aktif tentu ia akan mendengar suara hiruk pikuk pengajian, percakapan antar jama'ah, suara penceramah, serta suara alunan Al-Qur'an (Mansur, 2009).

Bahkan dalam majelis taklim atau pengajian seperti ini para jama'ah diawasi diagung-agungkan oleh malaikat dan dido'akan malaikat. Sang ibu juga senantiasa mengkomunikasikan kepada janin akan kegiatan majelis taklim dengan cara mengelus-elus perutnya dengan mengatakan bahwa sang janin diajak ikut serta bersama jam'ah lainnya. Sehingga hikmahnya sang janin mendapatkan insting kepekaan terhadap lingkungan yang relijius, perasaan gembira ketika berkumpul dengan orang sholih, dan terbiasa mendengarkan siraman rohani (Sarbini, 2010).

\section{Berdo'a dan berdzikir menjelang persalinan}

Mendekati proses melahirkan atau persalinan membuat rasa berdebar-debar baik suami maupun istri, apalagi kelahiran putra pertama. Tenaga dan pikiran benar-benar terkuras mempersiapkan momentum ini. 
Istri merasakan kepedihan setelah merasakan tanda-tanda lahir, merasakan kesakitan yang luar biasa. Hal ini harus diimbangi dengan berdo'a dan melantunkan zikir- zikir yang disunnahkan dan dicontohkan Rosululloh Shallallaahu 'alayhi wassalam ketika putrinya, Fatimah, saat hendak menjalani proses melahirkan. Ibnu Sunni meriwayatkan dengan sanad dhaif: Bahwasanya Fatimah Radiyallaahu'anha ketika sudah mendekati masa melahirkan, Rosululloh Shallallaahu 'alayhi wassalam memerintahkan ummu salamah dan Zainab binti Jahsy untuk datang dan membaca ayat kursi, surat Al-A'raf ayat 7, Surat Yunus ayat 3, surat Al-Falaq dan Surat An-Naas (Suwaid, 2010).

Hikmah dari membaca Do'a-do'a dan zikir yang bersumber dari ayat dan surat pilihan di atas agar sang ibu mendapat ketenangan, kekuatan fisik, kekuatan jiwa serta dijauhi dari pikiran-pikiran kacau. Sehingga sang ibu tidak hanya fokus merasakan sakit dan kepedihan dalam proses melahirkan tetapi juga menyibukkan lisan dan hatinya untuk senantiasa selalu mengingat Allah dalam keada apapun termasuk saat-saat genting seperti ini. Sang ibu membutuhkan kekuatan iman, dorongan yang bersumber dari kekuatan ilahiyah. Dalam menjalankan ini butuh peran suami atau orang tua yang sudah siap siaga mendampingi dalam proses persalinan. Dialah yang mengingatkan sang ibu untuk berdoa dan berzikir, mentalqin (membimbing dan membacakan) jika kondisi ibu sudah tidak menentu karea rasa sakit yang melanda (Suhermi \& Amirasti, 2020).

\section{Pendidikan Syari'at}

\section{Memberi makanan, minuman dan suplemen yang halal dan thoyyib.}

Ayah sang janin berupaya mencari rizki yang halal dimana hasil dari jerih payahnya dibelikan makanan dan minuman untuk ibu sang janin. Selain itu untuk mengoptimalkan tumbuh kembang janin, ayah ibu janin selalu memeriksakan janin dan memberi nutrisi berupa vitamin untuk mendongkrak tumbuh kembang secara normal. Makanan yang dibelikan untuk ibu akan dimakan serta oleh janinnya. Untuk itu sangat penting rizki diperoleh dengan jalan yang halal makanan yang halal akan berpengaruh karena mendapat ridho dari Allah bahwasanya tujuan makan adalah untuk menguatkan jasmani untuk beribadah (Lutfi, 2019).

Ayah dan ibu janin dianjurkan membeli vitamin ataupun suplemen sesuai anjuran dokter/bidan atau ahli gizi yang berkompeten dalam bidang kandungan.vitamin penting menjadi supply perkembangan janin dan menghindari kelainan/abnormal dalam proses tumbuh kembangnya. Jumlah dan kualitas makanan memberikan pengaruh signifikan terhadap perkembangan janin terkhusus makanan yang bisa dicerna dan dipergunakan. Pertumbuhan identik dengan jumlah/ukuran sedangkan perkembangan lebih identik kepada perubahan fungsi dan perubahan kompleksitas (Harini \& Al-Halwani, 2003). Misalnya pertumbuhan bisa dicontohkan berapa gram berat janin, sedangkan perkembangan bisa dicontohkan dalam hal detak jantung janin yang bisa dideteksi dan dipantau oleh alat kedokteran.

Hikmah dari makan yang thoyyib dan halal ini memberikan keridhoan Allah dan syarat terkabulnya doá. Sebab makanan yang haram baik jenis maupun cara memperolehnya dapat menghalangi terkabulnya doá seseorang.

\section{Pendidikan Al-Qur'an}

\section{Membaca dan memperdengarkan Al-Qur'an}

Al-Qur'an yang merupakan wahyu dari Allah tentu memberikan pengaruh bagi ketenangan jiwa sekaligus petunjuk hidup bagi manusia. Begitu pula bagi janin yang memang sudah berinteraksi dengan Allah dan mengikrarkan janji saat ditiupkan ruh ke dalam raganya. Waktu-waktu yang terbaik dan tepat dalam membacakan Al-Qur'an adalah ketika bayi berumur 18 minggu atau memasuki usia kandungan lima bulan. Pada saat itu bayi sudah mampu mendengar meski secara pasif (Mansur, 2009).

Sehingga hikmahnya adalah bacaan Al-Qur'an dapat mempengaruhi kecerdasan sang janin dan membiasakannya mendengarkan wahyu Allah sejak dalam kandungan. Terdapat sebuah penelitian pada anak juara satu penghafal Al Quran (Hafidz Cilik) di sebuah stasiun televisi swasta ternama, berdasarkan hasil wawancara, ibu sang anak memulai pendidikan AlQurán sejak dinyatakan positif hamil. Semenjak itu beliau rutin membacakan Al Quran satu hari satu juz, sehingga setiap bulannya khatam 30 juz. Sang ibu yakin dan percaya bahwa membaca AlQuran memberikan pengaruh yang positif terhadap janin yang 
dikandungnya. Selain itu membaca AlQuran memberi dampak bagi kecerdasan janin yakni kecerdasan intelektual (IQ), kecerdasan emosional dan spiritual (ESQ) (Islamiah et al., 2019).

Membaca Alquran secara teknis dibacakan oleh ibunya sendiri dengan mengagendakannya secara rutin dan terbiasa misal selepas sholat subuh, sehabis maghrib bahkan sebelum tidur ketika sang ibu berbaring sambil mengelus-elus perutnya. Membaca tidak selalu identik dengan melihat mushaf AlQur'an tetapi juga bisa melalui hafalan. Sang Ayah atau anggota keluarga lain juga bisa turut berperan membacakan Al-Qur'an di depan perut sang janin yang disimak langsung oleh ibunya. Dari pemaparan tersebut, pendidikan islam masa pre-natal disajikan pada Gambar 2.

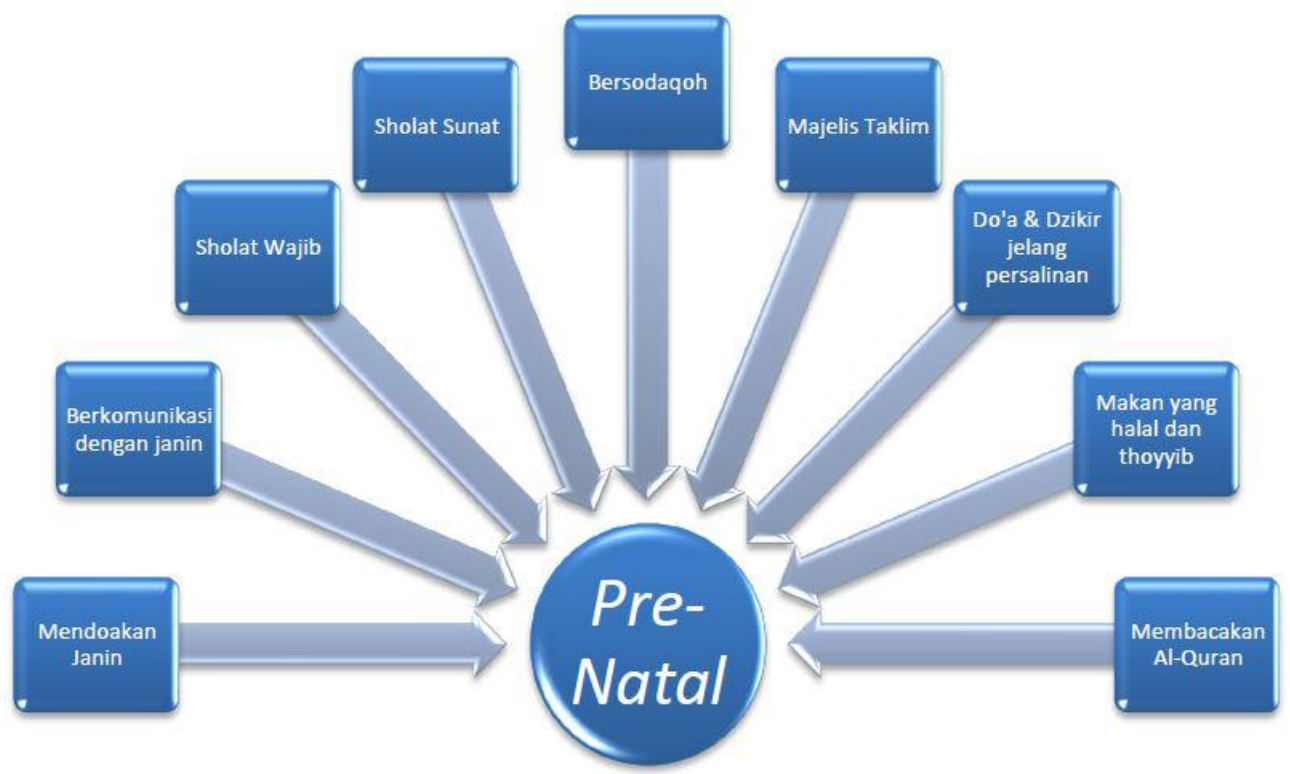

Gambar 2. Pendidikan Islam pada Masa Pre-Natal (Janin dalam Kandungan)

\section{Pendidikan Islam pada Anak masa postnatal}

Istilah Post-natal berasal dari kata post dan natal. Post berarti sesudah dan natal berarti lahir, sehingga jika digabungkan artinya adalah sesudah kelahiran. Pendidikan dalam masa pasca kelahiran atau persalinan tidak hanya ayah ibu yang berperan tetapi orang-orang sekelilingnya terutama keluarga juga turut berperan seperti ayah ibu mertua, kakak ataupun keluarga. Berikut ini adalah bentuk-bentuk pendidikan islam masa post-natal yang bisa dikategorikan menjadi setelah persalinan sampai anak selesai menyusui (menyapih).

\section{Pendidikan Aqidah}

\section{Mengazani pada telinga kanan bayi, dan mengiqomati sebelah telinga kiri bayi.}

Selepas melahirkan, setelah bayi dibersihkan dan diberi pakaian (dibedong), maka sesuai perilaku Nabi yang pernah dilakukan ketika cucu kembarnya lahir yakni Hasan dan Husein, sang bayi dikumandangkan azan oleh beliau. Jika tidak ada sang ayah, juga bisa digantikan oleh anggota keluarga yang lain. Nabi pun begitu, bukan Ali Radiyallahu 'anha selaku ayahnya melainkan Nabi sang kakek yang mengazani cucunya. Sebagaimana bunyi hadits yang diriwayatkan oleh Imam Ahmad dan At-Tirmidzi yang artinya : Bahwasanya Rasulullah membaca azan di telinga Al-Hasan bin Ali sesaat setelah Fatimah melahirkannya dengan azan untuk sholat. Hikmah diazankannya bayi baru lahir diantaranya dapat mengusir syetan. Sebab syetan ini mengintai bayi sejak awal dilahirkan. Dengan disenandungkannya azan dan iqomah di telinga bayi ini dapat melemahkan syetan (Suwaid, 2010).

\section{Memberi nama yang baik}

Salah satu kewajiban orang tua ketika anaknya lahir adalah memberikan nama yang baik. Nama yang memiliki makna positif bukan negatif. Biasanya orang tua zaman sekarang sudah memperispkan nama jauh- 
jauh hari bahkan semasa anak masih dalam kandungan ibunya. Hal ini sesuai kesepakatan orang tuanya dalam pemilihan nama, baik nama panjang dan nama panggilannya. Untuk anak laki-laki misalnya, Nama yang paling baik adalah "Abdullah" yang berarti "Abdi Allah" dan "Abdurrahman" yang berarti "hamba Allah yang penyayang", supaya ketika anak sudah sadar dan berakal, dia mulai paham akan makna namanya dan mengetahui bahwa dirinya hamba Allah dan Allah adalah dzat yang memimpin dan mengatur manusia dan alam semesta (Adil bin Yusuf, 2018). Dalam sebuah hadits yang diriwayatkan Al-Bukhari dari Sa'id ibn Musayyab, dari Ayahnya (Al-Adawy, 2011)

Suatu ketika ia bertandang ke rumah Rosullullah مح dan bertanya, "Siapa namamu?" ia menjawab "Huzn" (kesedihan), Rosullullah مح bersabda, "namamu (sekarang adalah) Sahl (kemudahan)." Orang itu berkata, "Aku tidak akan merubah nama yang telah diberikan Ayahku." Ibnu Musayyab berkata, "Akhirnya 'kesedihan' sama sekali tidak beranjak dari kami" Rosulullah bersabda. "Aslam, Allah menyelamatkannya; Ghifar, Allah mengampuninya; dan Ushiyah, ia durhaka kepada Allah danRosul-Nya." Dalam Shahih Bukhari diriwayatkan sebuah hadits, dengan sanad mursal, dari Ikrimah, ia berkata, "Ketika Suhail (yang mudah) ibn Amr datang, Nabi bersabda, "Urusan kalian menjadi mudah."

Hikmah memberi nama yang baik adalah memberi pengaruh yang besar bagi anak ke depannya nanti, pengaruh positif pada kepribadiannya, wataknya dan kepercayaan diri dalam bergaul kepada masyarakat. Dari hadits diatas mengemukakan betapa pentingnya memberi nama baik dan islami ketimbang nama-nama yang keji dan bermakna negatif (Taubah, 2015).

\section{Mengenalkan kalimat tauhid}

Apabila anak mulai bisa mengoceh atau berbicara, katakanlah kepada sang anak dengan kalimat tauhid "Laa ilaha illa Allah, Muhammad Rasulullah". Kalimat ini diajarkan sesuai kemampuan bahasa anak, misal dengan metode mengeja, anak diminta menirukan bacaan ini. Hikmah dari mengenalkan kalimat tauhid ini dilakukan agar suara pertama kali yang mengetuk indra pendengaran anak adalah berisi pengenalan kepada Allah dan ketauhidan. Tidak seperti orang-orang bani israil dahulu yang memperdengarkan kepada anak mereka dengan kalimat "Ma'maan Wail" yang artinya : Tuhan bersama kita" (Zekky, 2017).

\section{Pendidikan Ibadah}

\section{Do'a setelah melahirkan}

Mendo'akan anak setiap waktu baik ketika sesudah sholat 5 waktu, di dalam sujud ketika sholat sunnah maupun di luar sholat. Do'a adalah senjata bagi muslim dalam mengatur strategi lika-liku kehidupannya termasuk dalam mendidik anaknya. Orang tua harus memahami juga bahwa anak/bayi itu adalah milik Allah semata dan hanya dititipkan kepada manusia. Ada do'a yang pernah dicontohkan oleh Nabi Ibrahim 'alaihissalam setelah Allah memberikannya keturunan yaitu Ismail yang juga kelak menjadi pewaris nabi (Thalib, 2008). Do'a tersebut termaktub dalam AlQur'an surat Ibrahim ayat 40-41 yang berbunyi

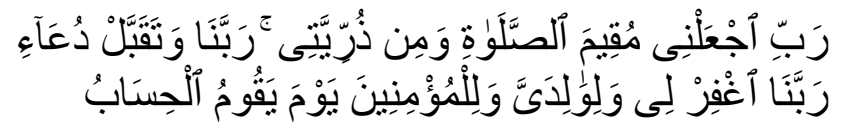

Ya Tuhanku, jadikanlah aku dan anak cucuku orang-orang yang tetap mendirikan shalat, ya Tuhan kami, perkenankanlah doaku. [Ibrahim:40]. Ya Tuhan kami, beri ampunlah aku dan kedua ibu bapaku dan sekalian orang-orang mukmin pada hari terjadinya hisab (hari kiamat)". [Ibrahim:41]. Itulah do'a yang pernah dicontohkan oleh Nabi Ibrahim 'alaihissalam. Selain itu, bisa ditambahkan dengan bahasa sendiri dan kalimat sendiri apa yang dikehendaki oleh orang tua sang janin, sebab Allah maha mengetahui dan maha mendengar permintaan hamba-Nya yang bersungguh-sungguh memohon. Hikmah dari doa setelah melahirkan ini agar orang tua bayi terutama ibunya dapat mensyukuri nikmat karunia Allah berupa keturunan karena tidak semua manuisa dikarunia keturunan. Selain itu hikmah lainnya mengagungi kebesaran Allah dimana tanpa kekuatan doá dan pertolongan Allah sebagai hamba tidak ada daya melahirkan dengan lancar tanpa izin dari-Nya. 


\section{Menyuapi bayi dengan kurma}

Pada sebuah hadits dijelaskan perilaku Rosulullah حمح dalam kitab shahih Bukhari dan Shahih Muslim disebutkan dari Abu Musa Radiyallahu 'anhu, ia berkata : "Aku mendapatkan seorang anak. Aku membawanya menghadap Nabi محم. Beliau memberinya nama Ibrahim." Kemudian beliau menyuapinya dengan sebutir kurma dan mendo'akan keberkahan padanya lalu menyerahkannya padaku (Suwaid, 2010).

Zaman sekarang terkadang masih ada kekhawatiran orang tua bayi dan keluarganya jika memberi makanan selain asi. Apalagi kurma yang secara tekstur masih padat dan perlu dikaji dalam ilmu kesehatan apakah aman jika disuapkan kepada bayi. Ada cara lain jika ada kekhawatiran misalnya dengan memberikan kurma sudah berbentuk ekstrak atau sari, yakni sari kurma. Sari kurma inilah yang disuapkan ke mulut bayi. Ini menjadi alternatif lain selain memberi lumatan kurma kepada bayi mengingat tekstur kurma yang masih kasar dan berserat. Hikmah atau pelajaran dari menyuapi bayi dengan kurma ini adalah disunnahkannya membawa bayi kepada orang sholeh dan minta keberkahan dan do'a darinya. Selain itu, menganjurkan supaya orang-orang bersikap lemah lembut, baik dan kasih sayang kepada anak-anak.

\section{Pendidikan Akhlak}

\section{Ucapan selamat dan mengumumkan kelahiran bayi}

Tidak hanya keluarga yang memperoleh anggota baru, kehadiran bayi juga menjadi bagian dari anggota baru dalam masyarakat. Sudah selayaknya orang tua bayi mengumumkan kelahirannya kepada keluarga, handai taulan, tetangga yang merupakan bagian dari masyarakat. Memberi ucapan selamat sudah selazimnya diberikan kepada orang tua bayi sebagai ungkapan simpati kepada sesama warga masyarakat. Orangtua bayi pun merasa gembira dan bahagia diperhatikan. Semua masyarakat hendaknya memberikan ucapan selamat kepada orangtuanya untuk meneladani ucapan selamat dari para malaikat kepada rosulrosul-Nya sebagaimana firman Allah

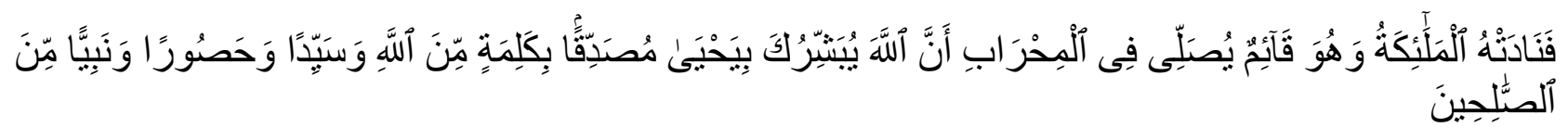

Kemudian Malaikat (Jibril) memanggil Zakariya, sedang ia tengah berdiri melakukan shalat di mihrab (katanya): "Sesungguhnya Allah menggembirakan kamu dengan kelahiran (seorang puteramu) Yahya, yang membenarkan kalimat (yang datang) dari Allah, menjadi ikutan, menahan diri (dari hawa nafsu) dan seorang Nabi termasuk keturunan orang-orang saleh". [Al 'Imran:39]. Hikmah dari ucapan selamat adalah yang pertama sebagai bentuk simpatik, ikut merasa bahagia, senang akan kehadiran bayi yang merupakan rejeki dari Allah. Kedua, bayi dan orangtuanya mendapatkan perhatian, dukungan sesama saudara dan masyarakat. Perhatian bisa dalam bentuk kasih sayang, memberi kado (bingkisan) yang berguna untuk bayi, ucapan serta nasihat-nasihat yang berguna untuk perkembangan bayi ke depan. Sedangkan hikmah dari mengumumkannya kelahiran bayi adalah yang pertama sebagai bentuk sosialisasi dengan keluarga dan warga sekitar akan hadirnya anggota masyarakat yang baru sehingga butuh akuisisi/pengakuan dari warga masyarakat. Hikmah yang kedua adalah menghindari fitnah karena kehadiran bayi memang benar dari hasil perkawinan yang sah secara syariát, tidak ditutup-tutupi.

\section{Mengenalkan kalimat-kalimat thoyyibah}

Mengenalkan bayi kalimat thoyyibah dapat dilakukan dengan cara melafazkan kalimat thoyyibah di saat melakukan aktifitas yang sesuai. Kalimat thoyyibah antara lain kalimat tasbih, tahmid, takbir dan tahlil. Memuji kebesaran Allah (tahmid) dengan mengucapkan alhamdulillah ketika mensyukuri nikmat Allah, misal ketika menyuapi anak makan, kalimat tasbih diucapkan misal dengan melihat tumbuhan/pohon di sekitar rumah, hewan sekitar, misal ada kucing bayi diajak berbicara dengan mengatakan : "dek, kucing ini lucu ya dek, kesayangan Nabi Muhammad, subhanallah ciptaan Allah!".

Hikmah dari mengenalkan kalimat-kalimat thoyyibah ini adalah lisan anak terbiasa mengucapkan kalimat-kalimat positif. Dan terbiasa mengagungkan nama-nama Allah sejak dini dan akan terbawa sampai dewasa kelak. Selain itu, secara tidak langsung membiasakan anak berdzikir ketika melihat, mengerjakan atau mengalami sesuatu dalam kesehariannya kelak. 


\section{Membacakan doa-doa harian}

Membiasakan anak beraktifitas sejak bangun tidur pagi hari sampai dengan tidur kembali di malam hari. Mulai dari do'a bangun tidur, doa sebelum mandi pagi, do'a berpakaian, do'a sebelum menyusui, doa sebelum dan sesudah makan (jika sudah makan MPASI), doa selepas buang air kecil dan sehabis buang air besar (dengan disertai tanda-tandanya seperti anak ngeden dalam bahasa jawa). Hikmah dari membacakan doá terhadap anak adalah, anak akan terbiasa memulai dan menyudahi aktifitas dengan mengimani Tuhannya. Sang anak memohon dan mempercayai adanya kekuatan Allah dalam jiwanya. Sehingga harapannya anak selalu dijaga Allah dan merasa diawasi oleh para malaikat.

\section{Pendidikan Fikih}

\section{Mencukur rambut kepala anak}

Mencukur rambut bayi termasuk sunnah, yakni dilaksanakan hari ketujuh setelah kelahirannya. Helaian rambut yang terpotong itu dikumpulkan dan ditimbang. Setelah itu berat hasil timbangannya ditukarkan dengan menyedekahkan uang perak kepada orang-orang fakir dan orang-orang yang berhak menerima seberat hasil timbangan rambut sang bayi (Ulwan, 2007). Hikmah yang bisa dipetik dari mencukur rambut bayi antara lain: Menjaga Kesehatan dengan mencukur rambu kepala bayi maka daya tahan tubuh anak semakin kuat dan kebal, membuka selaput kulit kepala yang belum bersih total karena bekas cairan ketuban yang mungkin masih melekat di kulit kepala, serta mempertajam indra penglihatan, pendengaran dan penciuman (Azizah, 2019).

\section{Aqiqah}

Aqiqah adalah menyembelih kambing sebagai wujud kesyukuran atas kelahiran bayi dan sesuai anjuran Rosulullah محم Ketentuan untuk bayi laki- laki sebanyak 2 ekor sedangkan perempuan satu ekor. Sebagimana hadits yang diriwayatkan oleh Ahmad, At-tirmidzi, Abu Dawud, An-Nasa'i, Al- Hakim, dan Ibnu Hibban dalam shahihnya dari Ummu Kurz Al-Ka'biyah, ia berkata: Bahwasanya dia bertanya kepada Rosulullah خ tentang aqiqah. Beliau menjawab, "Anak laki-laki dua ekor kambing, dan anak perempuan satu ekor kambing. Tidak apa-apa kambing-kambing itu jantan atau betina". Hikmah dari Aqiqah ini antara lain ; sebagai pemberitahuan tentang garis keturunan dengan cara yang baik kepada masyarakat luas dan menghindari fitnah yang tidak dikehendaki. Selain itu, Aqiqah dapat menumbuhkan rasa berbagi, dermawan, sosial dan empati kepada orang lain.

\section{Berkhitan}

Berkhitan secara istilah mengandung arti memotong lingkar kulit yang berada di ujung kepala kemaluan. Sebagaimana disebutkan dalam hadits shahih Bukhari dan Shahih Muslim dari hadits Abu Hurairah Radiyallahu 'anhu (Suwaid, 2010). Rosulullah طحم bersabda : "Fitrah ada lima : khitan, menukur bulu kemaluan, mencukur kumis, memotong kuku, dan mencabut bulu ketiak". Hikmah atau pelajaran dari berkhitan antara lain ; Khitan mengandung makna kesucian dan fitrah seorang muslim dan membedakan dengan pemeluk agama lainnya. Berkhitan juga dapat membedakan antara muslim dengan kafir. Perintah pertama kali turun kepada nabi Ibrahim, beliaulah manusia pertama yang diberkhitan pada usia 80 tahun.

\section{Menyusui dan Menyapih}

Memberikan hak anak (bayi) dengan menyusui anak selama 2 tahun. Dalam masa 2 (dua) tahun ini dimaksudkan hak anak yang diperoleh selama anak masih membutuhkan susu ibunya. Sebagaimana difirmankan Allah dalam Al- Qur'an :

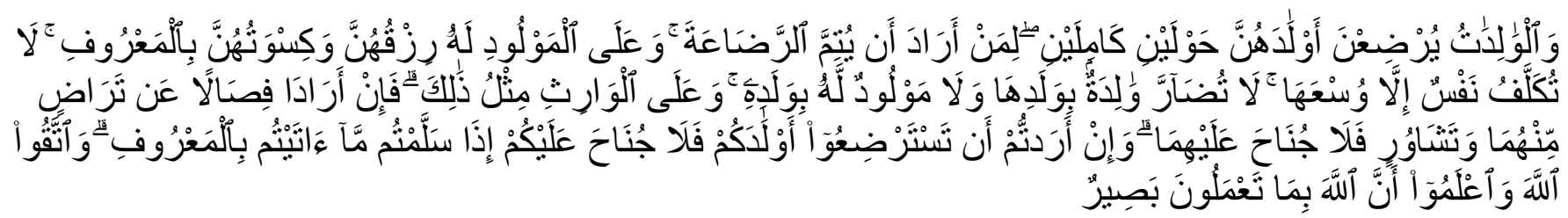


Para ibu hendaklah menyusukan anak-anaknya selama dua tahun penuh, yaitu bagi yang ingin menyempurnakan penyusuan. Dan kewajiban ayah memberi makan dan pakaian kepada para ibu dengan cara ma'ruf. Seseorang tidak dibebani melainkan menurut kadar kesanggupannya. Janganlah seorang ibu menderita kesengsaraan karena anaknya dan seorang ayah karena anaknya, dan warispun berkewajiban demikian. Apabila keduanya ingin menyapih (sebelum dua tahun) dengan kerelaan keduanya dan permusyawaratan, maka tidak ada dosa atas keduanya. Dan jika kamu ingin anakmu disusukan oleh orang lain, maka tidak ada dosa bagimu apabila kamu memberikan pembayaran menurut yang patut. Bertakwalah kamu kepada Allah dan ketahuilah bahwa Allah Maha Melihat apa yang kamu kerjakan. [Al Baqarah:233].

Ayat diatas menerangkan tentang anjuran menyusui anak selama dua tahun penuh. Namun jika ada suatu kondisi yang menyebabkan kurang dari 2 tahun anak mau disapihpun tidak mengapa, asal sudah disepakati bersama orangtua bayi atau keluarga. Apabila anak mau disapih sebelum genap 2 tahun atau kurang dari 2 tahun, maka perlu dimusyawarahkan orangtuanya, dengan mempertimbangkan aspek keselamatan jiwa dan kesehatan sang anak.

Hikmah dari menyusui anak adalah yang pertama; dari segi kesehatan Air Susu Ibu (ASI) dapat memberikan gizi, nutrisi, makanan terbaik yang dibutuhkan selama tumbuh kembang bayi. Kedua, dari segi psikologi, selain mempengaruhi fisik bayi, ASI juga mempengaruhi akhlak dan wataknya. Saat sang ibu menyusui bayinya, bukan sekedar memberikan ASI semata tetapi dengan kasih sayang, kelembutan, sentuhan tangan ibu (misalnya dengan membelai rambut, menepuk-nepuk pantat bayi). Sehingga insting kasih sayang itulah yang akan tumbuh pada jiwa sang bayi dan mempengaruhi tumbuh kembangnya kelak sampai dewasa. ASI yang bersumber dari darah ibu berproses menjadi ASI yang dihisap dan ditelan oleh anak kemudian berkembang menjadi darah, daging, otak, tulang menjadi fisik yang sempurna sang bayi (Ismail, 2018). Sedangkan menyapih memberikan hikmah adanya batasan hak anak dalam menyusui maksimal dua tahun penuh, bahkan boleh kurang dari itu (sesuai kondisi ibu) dan membiasakan anak memasuki tahap berikutnya yaitu mendapat asupan dari makanan lain selain air susu ibu.

\section{Pendidikan Al-Qur'an}

\section{Melantunkan bacaan Al-Qur'an di depan sang bayi saat ia terjaga dan tertidur.}

Anak baru lahir sebaiknya sering diperdengarkan bacaan al-qur'an baik itu langsung dari lidah orangtuanya ataupun rekaman audio/video. Saat ini sudah bisa diputar melalui aplikasi di smartphone, alat pemutar murottal seperti speaker quran, komputer dan lain-lain. Melantunkan bacaan Al-Qur'an di depan sang bayi, sehingga dia sangat familiar dan terkesima dengan bacaan Al-Qur'an. Pengalaman penulis, ketika melantunkan bacaan Al-Qur'an sang bayi memusatkan perhatian (bahkan tidak bergeming) serta antusias karena suara itu dan melihat ekspresi mimik mulut dan muka orang yang membaca Alquran di depannya, apalagi orang tuanya menirukan irama khas imam/syeikh tertentu yang ada pada rekaman audio Alquran yang rutin diperdengarkan bayi ketika mata terpejam (dibawah kesadaran) atau ketika melek.

Hikmahnya adalah bayi mendapatkan pengalaman berupa kebiasaan mendengar bacaan Al-Qur'an, jika bayi sudah besar dan berbicara dapat memudahkan menghafal Alquran menjadi hafidz Alquran sejak usia dini bahkan sejak bayi. Dalam tausiyah seorang pemuka agama mengatakan, jika ingin bayi besarnya nanti menjadi hafidz Al-quran sebanyak 30 juz, maka putarlah mp3/rekaman audio ketika bayi tertidur. Lakukan secara rutin dengan dimulai dari juz pertama surat Al-baqoroh selama sebulan, bulan berikutnya surat kedua, dan seterusnya sampai juz 30. Pada prinsip-prinsip belajar dan mendidik anak, belajar merupakan sebuah proses, butuh waktu yang cukup panjang dan berulang-ulang. Dalam kaidah pembelajaran bahasa Arab pun begitu, awal- awal belajar bahasa para peserta dibisakan istima' (mendengar) intruksi bahasa Arab yang asing di telinganya. Selain itu, prinsip belajar lainnya adalah sang anak belajar dengan cara bisa meniru orang tua atau orang yang banyak menghabiskan waktu bersama sang anak (Kemenag RI, 2017). Pada saat anak tertidur, orang tua juga bisa memperdengarkan rekaman bacaan Alquran sat dia tertidur. Ketika tertidur audio Hal ini diharapkan dapat masuk ke dalam alam bawah sadar, dan juga menghindarkan diri dari gangguan jin/syetan dan mimpi buruk. 


\section{Pendidikan Tarikh/Sejarah}

\section{Membacakan cerita}

Membacakan cerita kepada bayi juga mampu mendayagunakan indera penglihatan dan pendengarannya. Terutama ketika orangtua menggunakan media buku bergambar sehingga bisa mewakili visualisasi anak terhadap materi cerita, terutama cerita sejarah. Cerita sejarah disini baiknya mengandung materi kisah yang shahih dari Al-Qurán. Sebaiknya orangtua banyak mengambil kisah-kisah yang dicantumkan Al-Qurán dan menghindarkan dari kebohongan, mengutamakan kisah nyata dari Al-Qurán dan menghindari dongeng karena dongeng hanya berisi dugaan dan karangan manusia. Sebagaimana disebutkan dalam firman Allah berikut: Dan diantara mereka ada yang buta huruf, tidak mengetahui Al Kitab (Taurat), kecuali dongengan bohong belaka dan mereka hanya menduga-duga [Al Baqarah:78]. Dari ayat tersebut dapat menjadi renungan untuk orangtua supaya memprioritaskan kisah daripada dongeng. Jangan sampai anak terkontaminasi dan didominasi oleh cerita rekaan karena dapat mempengaruhi jalan pikiran anak. Metode membacakan cerita bisa dengan cara membacakan langsung buku cerita di depan anak, memperlihatkan kartu bergambar tempat bersejarah, nama tokoh sejarah, nama-nama nabi dan sahabat dan lain sebagainya.

Hikmah dari membacakan cerita terutama kisah para nabi dan orang-orang sholeh terdahulu adalah dapat menanamkan karakter anak yang berwawasan luas serta membentuk pola pikirnya terhadap sejarah. Selain itu pula dapat mempengaruhi jalan pikiran anak, mengenalkan kosakata baru ataupun perbendaharaan kata yang baru, membantu perkembangan moral dan sosial anak. Melatih kemampuan visualisasi, dan menstimulus minat baca tulis anak (Mujahidin, 2018).

\section{SIMIPULAN}

Pendidikan islam masa pre-natal (masa kehamilan) dapat disimpulkan menjadi beberapa rumpun pendidikan. Pendidikan aqidah antara lain: mendoakan janin, membangun komunikasi pada janin, pendidikan ibadah; sholat wajib, sholat sunnah, bershodaqoh, mengikuti majelis taklim dan berkumpul dengan orang sholeh, berdoá dan berdzikir menjelang persalinan. Pendidikan Syariát meliputi: memberikan makanan, minuman dan suplemen yang halal dan thoyyib. Pendidikan Al-Qurán: membaca dan memperdengarkan Al-Qurán. Sedangkan masa post-natal (masa persalinan) disimpulkan menjadi beberapa rumpun antara lain: Pendidikan Aqidah meliputi: Mengadzani dan mengiqomati bayi dan memberi nama yang baik dan mengenalkan kalimat tauhid. Pendidikan ibadah meliputi; berdoá setelah melahirkan, menyuapi bayi dengan kurma. Pendidikan Akhlak meliputi: ucapan selamat dan mengumumkan kelahiran bayi, mengenalkan kalimat-kalimat thoyyibah, membacakan doa-doa harian. Pendidikan Fikih: Mencukur rambut kepala anak, Aqiqah, berkhitan, menyusui dan menyapih. Pendidikan Al-Qurán: melantunkan bacaan Al-Qurán di depan sang bayi saat ia terjaga dan tertidur.

\section{DAFTAR RUJUKAN}

Adil bin Yusuf, A. (2018). Panduan kehamilan perspektif islam dan kedokteran modern. Qudsi Media.

Ak, B. (2000). Mendidik anak dalam kandungan: Menurut ajaran pedagogis Islami. Darul Ulum Press.

Al-Adawy, S. M. (2011). Fikih pendidikan anak: Membentuk kesalehan anak sejak dini. Qisthi Press.

Aziz, S. (2017). Pendidikan spiritual berbasis sufistik bagi anak usia dini dalam keluarga. Dialogia: Jurnal Studi Islam Dan Sosial, 15(1), 131-149.

Azizah, N. (2019). Nilai-nilai pendidikan Islam dalam hadis-hadis akikah. Jurnal Progress: Wahana Kreativitas Dan Intelektualitas, 7(1), 81-102.

Harini, S., \& Al-Halwani, A. F. (2003). Mendidik anak sejak dini. In Yogyakarta: Kreasi Wacana.

Islamiah, F., Fridani, L., \& Supena, A. (2019). Konsep pendidikan Hafidz Qur'an pada anak usia dini. Jurnal Obsesi: Jurnal Pendidikan Anak Usia Dini, 3(1), 30-38.

Ismail, H. (2018). Syariat menyusui dalam alquran (kajian Surat Al-Baqarah ayat 233). At-Tibyan: Jurnal Ilmu Alqur'an Dan Tafsir, 3(1), 56-68.

Kemenag RI. (2017). Fondasi keluarga sakinah bacaan mandiri calon pengantin (pp. 98-99). Subdit Bina Keluarga Sakinah, Direktorat Bina KUA \& Keluarga Sakinah Ditjen Bimas Islam.

Lutfi, M. (2019). Konsumsi dalam perspektif ilmu ekonomi Islam. Syar’ie, 1(Januari), 95-109.

Mansur, M. (2009). Mendidik anak sejak dalam kandungan (cetakan IV). Mitra Pustaka.

Mujahidin, E. (2018). Pengaruh materi cerita terhadap perkembangan kepribadian anak. Edukasi Islami: Jurnal Pendidikan Islam, 7(02), 211-228. 
Sarbini, A. (2010). Internalisasi nilai keIslaman melalui majelis taklim. Ilmu Dakwah: Academic Journal for Homiletic Studies, 5(16), 53-70.

Suhermi, S., \& Amirasti, S. (2020). Faktor yang berhubungan dengan kecemasan ibu primigravida menjelang persalinan. Window of Nursing Journal, 1(1), 7-14.

Suparman, D. (2015). Pembelajaran ibadah shalat dalam perpektif psikis dan medis. Jurnal Istek, 9(2), 48-70.

Suwaid, M. N. A. H. (2010). Prophetic parenting cara nabi mendidik anak. Pro-U Media.

Taubah, M. (2015). Pendidikan anak dalam keluarga perspektif Islam. Jurnal Pendidikan Agama Islam (Journal of Islamic Education Studies), 3(1), 109-136.

Thalib, M. (2008). Ensiklopedi keluarga sakinah.

Ulwan, A. N. (2007). Pendidikan anak dalam Islam. In Jakarta: Pustaka Amani. Pustaka Amani.

Zekky, S. (2017). Metode pendidikan tauhid dalam keluarga. Pendidikan Islam, 1(2), 1-21. 